\title{
COVID-19 and Heart: From Clinical Features to Pharmacological Implications
}

\author{
Vincenzo Russo*(D), Roberta Bottino ${ }^{\dagger}$, Andreina Carbone ${ }^{\dagger}(\mathbb{D}$, Anna Rago, Andrea Antonio Papa, \\ Paolo Golino and Gerardo Nigro $(\mathbb{D}$
}

Division of Cardiology, Department of Translational Medical Sciences, University of Campania “Luigi Vanvitelli", Monaldi Hospital, 80131 Naples, Italy; ro-bottino@hotmail.com (R.B.); andr.carbone@gmail.com (A.C.); anna_rago@alice.it (A.R.); andreantoniopapa@libero.it (A.A.P.); paolo.golino@unicampania.it (P.G.); gerardo.nigro@unicampania.it (G.N.)

* Correspondence: v.p.russo@libero.it

t These authors contribute equally to this work.

Received: 29 April 2020; Accepted: 10 June 2020; Published: 22 June 2020

Abstract: A highly pathogenic human coronavirus, severe acute respiratory syndrome coronavirus 2 (SARS-CoV-2), has been recently recognized in Wuhan, China, as the cause of the coronavirus disease 2019 (COVID-19) outbreak which has spread rapidly from China to other countries in the world, causing a pandemic with alarming morbidity and mortality. The emerging epidemiological data about COVID-19 patients suggest an association between cardiovascular diseases (CVD) and SARS-CoV-2 infection, in term of clinical features at hospital admission and prognosis for disease severity. The aim of our review is to describe the cardiological features of COVID-19 patients at admission, the acute cardiac presentation, the clinical outcome for patients with underlying CVD and the pharmacological implications for disease management.

Keywords: coronavirus disease 2019 (COVID-19); angiotensin-converting enzyme inhibitor; myocardial injury; cardiovascular diseases; cardiac biomarkers; arrhythmias

\section{Introduction}

Human coronaviruses (HCoVs) are enveloped non-segmented positive-strand RNA viruses, with rapid evolution owing to its high genomic nucleotide substitution rates and recombination. $\mathrm{HCoVs}$ are associated with multiple respiratory diseases of varying severity, including common cold, pneumonia and bronchiolitis. A highly pathogenic $\mathrm{HCoV}$, firstly identified as 2019-nCOV and now named severe acute respiratory syndrome coronavirus 2 (SARS-CoV-2), has been recently recognized in Wuhan, China, as the cause of the coronavirus disease 2019 (COVID-19) outbreak, with alarming morbidity and mortality. The clinical course of about 15\% of COVID-19 patients may be complicated by the onset of a severe interstitial pneumonia, which may then progress towards acute respiratory distress syndrome (ARDS) and/or multi organ failure (MOF) and death. There are many emerging data on patients' clinical features at hospital admission and on the factors influencing the prognosis in COVID-19 patients. The aim of our review is to describe the cardiological features of COVID-19 patients at admission, the acute cardiac presentation, the clinical outcome for patients with underlying cardiovascular diseases (CVD), the pharmacological implications for disease management.

\section{Pathogenetic Mechanisms}

SARS-CoV-2 has been classified by the World Health Organization (WHO) as a beta coronavirus of group $2 \mathrm{~B}$ for its acid sequence similarity with SARS-CoV and middle east respiratory syndrome (MERS)-CoV, the most pathogenic known beta coronaviruses [1,2]. SARS-CoV-2, as typical of 
coronaviruses, encodes at least 27 proteins, including 15 non-structural proteins, four structural proteins, and eight auxiliary proteins [3]. Among the structural proteins, spike glycoprotein $S(S)$ is located on the outer envelope of the virion and mediates surface entry of coronaviruses into host cells. Its biochemical composition consists of a large ectodomain, a single-pass transmembrane anchor, and a short C-terminal intracellular tail [4]. S1 receptor binding unit and S2 membrane fusion unit are part of the coronaviruses ectodomain of $S$ protein. The receptor binding domain (RBD) of the S1 unit determines the capability to enter host cells by binding a high affinity receptor while S2 unites allowing membrane fusion [4]. The S1 RBD of SARS-CoV-2 S glycoprotein was found to have almost identical 3-D structure and a high degree of homology with the RBD of SARS-CoV [4-6]. Previous studies have demonstrated that SARS-CoV RBD has a strong binding affinity to angiotensin-converting enzyme 2 (ACE2) human receptor $[7,8]$ and recently it has been demonstrated also for SARS-CoV-2 [9]. Moreover, it has been described that molecular differences in the RBD of SARS-CoV-2 give it potentially higher affinity binding for ACE2, increasing the ability of inter-human transmission [10,11]. Hence, the expression of ACE2 on the cell surface makes it susceptible to SARS-CoV-2 infection. Of note, such cells include type II alveolar cells (AT2) of the lungs [9]. Lung cells are the main target cells despite the fact that ACE2 receptor is widely expressed in non-pulmonary tissues [12-14]. The explanation may lie in the extensive expression of the receptor at the level of AT2 cells which therefore could act as reservoirs of infection [15]. In addition, type AT2 cells show high levels of genes required for viral replication [15]. Using single-cell RNA sequencing it has been established that heart, esophagus, kidney, bladder, and ileum are organs at risk for SARS-CoV-2 infection because of significant ACE2 receptor cell expression; according to the results, heart cells were identified as high vulnerable cells, especially during viremia [15].

\section{Cardiovascular Features of Infected Patients}

The epidemiological association between cardiovascular diseases or risk factors and HCoV infection has been previously demonstrated by many studies describing clinical features of SARS and MERS patients $[16,17]$. In particular hypertension and diabetes were the most prevalent comorbidities for SARS and MERS, and were found to be an independent predictor for mortality and morbidity in SARS patients $[16,17]$.

Since the early published cohort studies, including COVID-19 patients, it emerged that SARS-CoV-2 was more likely to affect older men with cardiovascular comorbidities [18-20]. Among the overall COVID-19 Chinese population, 23.7\% had at least one coexisting illness [21], mostly chronic disease, such as hypertension, diabetes and coronary artery disease [18-20,22-25]. Two recent meta-analyses on the clinical characteristics of COVID-19 patients reported the overall prevalence of cardiovascular and metabolic diseases [26,27]. In both studies, the most prevalent cardiovascular comorbidities were hypertension (17.1\% and $17 \%)$, cardio-cerebrovascular disease $(16.4 \%$ and $5 \%)$, and diabetes $(9.7 \%$ and $8 \%$ ) [26,27]. Males were more affected than females (57.8\% and 51.6\%, respectively) [26,27].

An analysis of 5700 patients with COVID-19 admitted to 12 hospitals in New York City, Long Island, and Westchester County from March 1, 2020, and April 4, 2020, showed the most common comorbidities were hypertension $(3026 ; 56.6 \%)$, obesity $(1737 ; 41.7 \%)$, and diabetes $(1808 ; 33.8 \%)$ [28]. Furthermore, 595 patients $(11 \%)$ had coronary artery disease and $371(6.9 \%)$ congestive heart failure. This study showed that older persons, men, and those with pre-existing hypertension and/or diabetes were highly prevalent and the pattern was similar to data reported from China [28]. A recent Italian multicenter observational study including 196 hospitalized patients confirmed the prevalence of cardiovascular risk (CV) factors in COVID-19 patients; in particular hypertension, diabetes and coronary artery disease were the most prevalent comorbidities [29]. Table 1 summarizes the cardiological clinical features of COVID 19 patients, in Chinese, American (U.S.) and Italian population, compared to those of SARS and MERS patients [17,28-30].

In conclusion, based on published studies including those on heterogeneous populations, it is not possible to identify a causal link between CVD and the individual susceptibility to SARS-CoV2 
infection; however, the emerging data suggest an epidemiological association with chronic CVD, in particular hypertension, diabetes and coronary artery disease. These clinical conditions should be considered potential risk factors for COVID-19 patients and should be included as red flag in future targeted public health vaccination interventions.

Table 1. Comparison between cardiological clinical features of SARS, MERS and COVID-19.

\begin{tabular}{|c|c|c|c|c|c|c|c|}
\hline \multirow{2}{*}{ Patients, $n$} & \multicolumn{2}{|c|}{ SARS $(28,30)$} & \multicolumn{2}{|c|}{ MERS $(17,30)$} & \multirow{2}{*}{$\begin{array}{c}\begin{array}{c}\text { COVID-19 (Chinese } \\
\text { report) }{ }^{(27)}\end{array} \\
46248\end{array}$} & \multirow{2}{*}{$\begin{array}{c}\text { COVID-19 (U.S. } \\
\text { report) }{ }^{(28)}\end{array}$} & \multirow{2}{*}{$\begin{array}{c}\begin{array}{c}\text { COVID-19 (Italian } \\
\text { report) })^{(29)}\end{array} \\
192\end{array}$} \\
\hline & 357 & 144 & 637 & 245 & & & \\
\hline Age, mean (range) & $45(34-57)$ & $45(34-57)$ & $53(35-65)$ & $53(36-66)$ & 56 & $63(52-75)$ & $67,7(52.5-80.9)$ \\
\hline Sex, male n $(\%)$ & $157(44)$ & $70(49)$ & $426(67)$ & $154(63)$ & $23,863(51,6)$ & $3437(60.3)$ & $115(59.9)$ \\
\hline Hypertension, $\mathrm{n}(\%)$ & - & - & $305(48)$ & $81(33)$ & $6474(17)$ & $3026(56.6)$ & $111(57.8)$ \\
\hline Diabetes, n (\%) & $21(5,9)$ & $16(11)$ & $324(51)$ & $76(31)$ & $3699(8)$ & $1808(33.8)$ & $42(21.9)$ \\
\hline $\begin{array}{l}\text { Cardiovascular } \\
\text { Disease, n (\%) }\end{array}$ & $24(6,7)$ & $17(12)$ & $197(31)$ & 37 (15) & 2312 (5) & $966(16,9)$ & $26(13.5)$ \\
\hline
\end{tabular}

\section{Myocardial Injury}

The pathogenesis of acute myocardial injury in the clinical context of COVID-19 remains unclear, however the following three mechanisms may play an important role in its genesis (Figure 1).

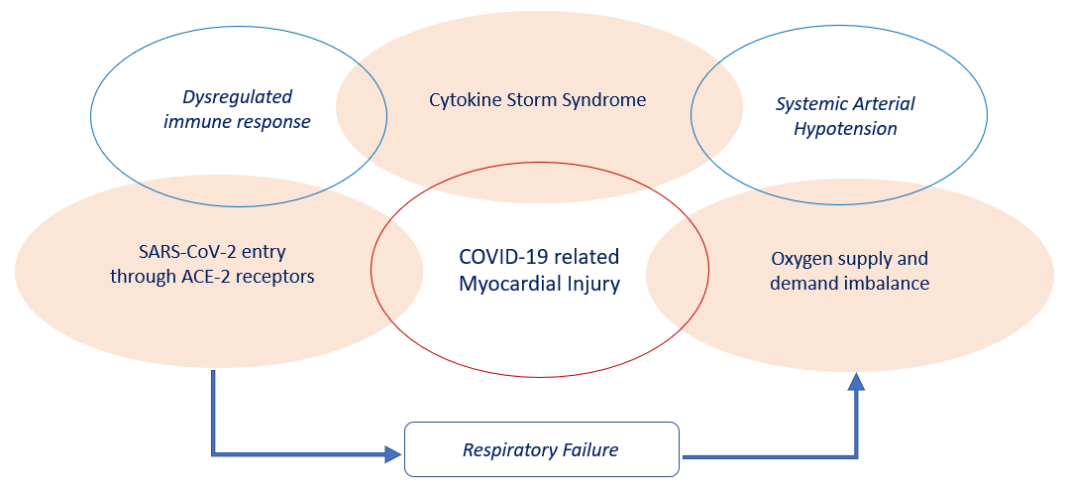

Figure 1. Mechanisms implicated in the pathogenesis of COVID-19 related myocardial injury.

First, SARS-CoV-2 may directly cause myocardial damage by entering cardiomyocytes using the ACE2 receptor, which is highly expressed in the heart [30]. Second, myocardial injury may result from the imbalance between oxygen supply and demand due to respiratory failure and systemic arterial hypotension, especially in patients with low ischemic threshold related to underlying CVD [31]. Third, the SARS-CoV-2 infection may lead to dysregulated immune response with higher neutrophil-lymphocyte-ratio (NLR), lower levels of both T helper and T suppressor cells, and higher expression of proinflammatory cytokines (i.e., tumor necrosis factor (TNF)- $\alpha$, interleukin (IL)-2R and IL-6), chemokines (IL-8), granulocyte-colony stimulating factor, interferon- $\gamma$ inducible protein 10 , monocyte chemoattractant protein 1 , macrophage inflammatory protein $1-\alpha[19,32]$.

This condition, known as "cytokine storm syndrome", might have a role in cardiovascular system injury, causing direct cardiac toxicity, a rapid onset of severe cardiac dysfunction and a vascular leakage with peripheral and pulmonary edema [33-35].

The myocardial zymogram, including the measurement of creatine kinase (CK) and lactate dehydrogenase (LDH) activities, was frequently described in COVID-19 cohort studies [18,21,25].

In a large multicenter retrospective study including 1099 COVID-19 confirmed patients from 552 hospitals in 31 provinces in China, the elevation of CK ( $\geq 200 \mathrm{U} / \mathrm{L})$ and LDH ( $\geq 250 \mathrm{U} / \mathrm{L})$ serum levels accounted to $13.7 \%$ and $41 \%$, respectively [21]. The CK and LDH abnormal serum levels were more highly expressed in critically ill patients (19\% and $58.1 \%$, respectively) and in those with major composite endpoint events, including admission to the ICU, invasive mechanical ventilation and death [21]. 
According to the fourth universal definition of myocardial infarction, myocardial injury is defined by an elevation of cardiac troponin (cTn) value above the 99th percentile URL [31]. The injury is considered acute if there is a rise and/or fall of cTn values [31]. Few studies have described myocardial injuries in COVID-19 patients and its impact on clinical prognosis needs to be clarified.

An early prospective study by Huang et al. [19], including 41 admitted hospital patients with laboratory-confirmed SAS-CoV-2 infection at Jin Yintan Hospital in Wuhan, showed a substantial increase of high sensitive troponin I (hs-cTnI) levels ( $>28 \mathrm{ng} / \mathrm{L})$ in five patients $(12 \%)$, in whom the diagnosis of virus-related cardiac injury was made. Four patients were admitted to the ICU, accounting for $31 \%$ of the total number of ICU patients [19].

In the retrospective, single-center case series by Wang et al. [23] including 138 consecutive patients with confirmed SAR-CoV-2 pneumonia hospitalized at Zhongnan Hospital of Wuhan University, ten cases $(7.2 \%)$ were diagnosed with acute myocardial injury. Among them, eight were admitted to the ICU, accounting for $22.2 \%$ of the total number of ICU patients [23].

In a retrospective, multicenter cohort study by Zhou et al. [22] including 191 COVID-19 patients from Jinyintan Hospital and Wuhan Pulmonary Hospital, Wuhan, China, 24 patients (17\%), out of 145 cases with troponin determinations, showed increased serum levels of $\mathrm{cTn}$ I ( $>28 \mathrm{ng} / \mathrm{mL})$ [22].

In a retrospective analysis by Chen et al. [20] including 150 COVID-19 patients admitted to Tongji Hospital, Tongji Medical College, Huazhong University of Science and Technology, in 22 cases $(14.7 \%)$ the cTnI value was elevated ( $>26.3 \mathrm{ng} / \mathrm{L}$ ); moreover, myocardial injury was present in $62.5 \%$ of patients in critical conditions and it seemed to be an independent risk factor (OR $=26.909,95 \%$ CI 4.086 to 177.226, $p=0.001$ ) for COVID-19 critical illness patients at multivariate analysis [20].

All these clinical studies, although heterogeneity was considerably high [36], have shown that cTnI serum levels were only marginally increased in COVID-19 patients at hospital admission, observing values exceeding the 99 th percentile in the upper reference limit (URL) in 7-17\% of hospital admitted positive cases. Moreover, cTnI values are significantly increased in COVID-19 critically ill patients compared to those with milder forms of disease [36].

These preliminary data suggest the hypothesis that early measurement, at hospital admission of cardiac damage biomarkers in COVID-19 patients, as well as longitudinal monitoring during hospital stay, may help to identify patients at increased risk of evolving toward a worse clinical condition.

\section{Myocardial Injury Pharmacological Treatment}

According to the expert recommendations for clinical management of myocardial injury associated with SARS-Cov-2 infection [37], in addition to close monitoring, symptomatic treatment and respiratory support, treatment with Sodium creatine phosphate ( $1 \mathrm{~g}$ once or twice daily, intravenous infusion within 30 to $45 \mathrm{~min}$ ); Coenzyme 1 (5 mg once daily, intravenous infusion); Coenzyme Q10) $10 \mathrm{mg}$ three times daily, orally]; Trimetazidine ( $20 \mathrm{mg}$ three times daily, orally); and Vitamin C (10 g once day intravenous drip, for 15 to 30 days) is recommended to improve myocardial energy metabolism.

In the clinical setting of acute myocardial infarction (AMI) with ST elevation (STEMI) in suspected or diagnosed SARS-CoV-2 infected patients, some Chinese authors [38] suggest performing percutaneous coronary intervention (PCI when hemodynamic instability is present and to prefer thrombolytic therapy in isolated conditions in the case of STEMI stable patient with symptoms onset time within 12h. Out of this temporal range or in AMI patients without ST elevation (NSTEMI) a comprehensive assessment of the risk-benefit ratio of PCI (given limited data on primary PCI benefit for type-2-MI from acute viral illness) and infection control or nosocomial infection should be performed.

A recent guidance from the European Society of Cardiology (ESC) for the diagnosis and management of CV Disease during the COVID-19 pandemic suggests considering all STEMI patients as positive to SARS-CoV-2 infection until laboratory results and to proceed with invasive treatment within $120 \mathrm{~min}$. Fibrinolysis should be performed only in cases where it is not possible to access the catheterization laboratory within two hours after diagnosis. Hemodynamically unstable NSTEMI patients need to be managed as in STEMI, otherwise management should be guided by risk stratification. 
In case of high risk stable patients, ESC guidance suggests postponing the angiographic study for up to $24 \mathrm{~h}$ to wait test results for SARS-CoV-2 infection [39]. In the remaining cases it is always useful to wait for the results of anti-SARS-CoV-2 tests, dismissing alternative diagnoses using non-invasive diagnostic strategies to make risk stratification more accurate and faster in order to decide possibly upon a conservative strategy and rapid hospital discharge [39]. In all cases (STEMI and NSTEMI), testing for SARS-CoV-2 infection should be performed as soon as possible irrespective of treatment of choice and positive patients managed in a COVID-19 hospital.

\section{Myocarditis}

Myocarditis is an inflammatory disease of the myocardium, diagnosed by established histological, immunological and immune-histochemical criteria, caused by infectious, immune-mediated or toxic agents [40]. A previous case report described coronavirus-associated myocarditis in animal models [41], as well as in humans during MERS-CoV infection [42].

To date, sporadic cases of myocarditis have been reported in COVID-19 patients at first clinical presentation of disease [43,44], alone or in the clinical context of pneumonia [45].

In two Chinese cohort studies including 334 and 150 COVID-19 patients respectively, the prevalence of myocarditis ranged from $0.3 \%$ to $7 \%[46,47]$.

Based on published data, SARS-CoV-2 may represent a potential novel etiology of fulminant myocarditis. It should be suspected in COVID-19 patients with acute-onset chest pain, ST segment changes, cardiac arrhythmias, and hemodynamic instability. In addition, left ventricular dilatation, global/multi-segmental left ventricular hypo-contractility [on echocardiography), and significant increase in cardiac troponin levels, without significant coronary artery disease, could also be present [39].

Actually, even if cardiac injury is not uncommon in COVID-19 patients, myocarditis seems to be a rare event, but when occurring, appears early in patients' clinical history [48].

\section{Arrhythmias}

There are few and conflicting data about the occurrence of arrhythmias in the context of COVID-19; however, the clinical presentation seems to be not different from those described in the general population (i.e., palpitations, dyspnea, dizziness, chest pain, syncope, etc.) and occurs in $7.3 \%$ of COVID-19 cases as the initial symptom of the myocardial involvement [49].

In a cohort study by Chen et al. [20] including 150 COVID-19 patients, arrhythmias were present at admission only in $1.3 \%$ of patients. In the cohort study by Wang et al. [23] an arrhythmia complicated the clinical course of the disease during hospitalization in 16.7\% of COVID-19 patients; moreover, arrhythmias were significantly higher in patients receiving ICU care than in those not receiving ICU care $(44.4 \%$ vs. $6.9 \% ; \mathrm{P}<0.001)$. In both studies, the authors did not describe the type and duration of arrhythmias.

In contrast to these early experiences, the two largest observational studies, including 1099 Chinese and 5700 U.S. COVID-19 patients respectively, did not report any arrhythmias [21,28]. A recent Italian multicenter observational study showed a prevalence of $12.5 \%$ among hospitalized COVID-19 patients [29]; moreover, a report by the COVID-19 Task Force of the Italian National Institute of Health showed that $22.5 \%$ of non-surviving COVID-19 patients (n: 355 , mean age 79.5 years, $30 \%$ women) presented atrial fibrillation as comorbidity diagnosed before the SARS-CoV-2 infection [50]. The approach to atrial fibrillation (AF) management should take into consideration several pharmacological interactions between antiarrhythmic and experimental COVID-19 therapies [51]

Ventricular arrhythmias seem to be directly correlated to COVID-19 induced myocardial injury Among a cohort of 187 COVID-19 patients without history of arrhythmias, the subjects with elevated TnT levels more frequently developed malignant arrhythmias, including ventricular tachycardia and fibrillation during hospitalization (2 (1.5\%) vs. 9 (17.3\%) compared to those with normal TnT levels [52].

Based on these few data, arrhythmias represent a not rare clinical presentation of COVID-19 that could complicate the clinical course of the disease during hospitalization and worsen the prognosis 
of infected patients, presenting high prevalence in not-survived patients. For this reason, careful electrocardiographic monitoring should be performed in COVID19 patients to early detect paroxysmal arrythmia that does not match the disease status and might be a red flag of worsening disease [53].

\section{Heart Failure}

Heart failure (HF) was reported by Zhou et al. in 23.0\% of hospitalized COVID-19 patients and it was more common in patients who did not survive the hospitalization compared to those who did survive $(51.9 \%$ vs. $11.7 \%, p<0.001)$ [22]. The high HF prevalence among COVID-19 patients might be related to failure of pre-existing cardiomyopathy with impaired left ventricular function or it might be consequent to COVID-19 related myocardial injury, both through direct and immune-mediated mechanisms. Right heart failure with increased pulmonary vascular resistance and pulmonary hypertension should also be considered, especially in the context of moderate-severe pneumonia and ARDS [53]. The coexistence of HF and COVID-19 makes diagnosis and management more complicated [54]; however, there are significant differences in chest CT when HF stands alone or is diagnosed simultaneously with COVID-19 such as enlargement of pulmonary veins, lesions distribution and morphology [54]. Based on published data, heart failure might represent a severe complication of COVID-19. The early recognition of HF symptoms and timely HF treatment may be of pivotal importance to improve the prognosis of COVID-19 patients: in fact, when heart failure falls into cardiogenic shock, refractory to therapy, the treatment of these patients becomes rather complicated [55]. In presence of cardiogenic shock, refractory to therapy, the Extracorporeal Life Support Organization [ELSO] guidelines recommend the use of veno-arterial extra corporeal membrane oxygenation (VA-ECMO) as the bridge to recovery [56]. As far as cardiogenic shock complicating COVID-19 is concerned, little evidence is offered for the use of VA-ECMO in these patients $[44,57]$. Given the lack of documented experience, some working groups have proposed general recommendations for the use of this intensive care treatment, focusing attention on the patient's age, the presence of sepsis, the coagulation status, and the presence of ARDS and/or MOF, whose presence can frustrate the use of this device $[58,59]$.

\section{Cardiovascular Outcomes}

The evidence emerging from the early Chinese cohort study including COVID-19 patients showed a significantly increased prevalence of cardiovascular diseases (CVD) in critically ill patients compared to those with milder forms of disease $[18,23]$ and, in the same way, in non-surviving COVID-19 patients compared to survivors [46]. In a retrospective analysis by Chen et al. [20] including 150 COVID-19 patients, a history of coronary heart disease was present in $6.7 \%$ of patients in critical conditions and this seemed to be an independent risk factor for the need of ICU care at multivariate analysis $(\mathrm{OR}=16.609,95 \%$ CI $2.288 \sim 120.577, p=0.005)$.

Zhou et al. [22] in a retrospective multicenter cohort study including 191 COVID-19 patients (median age 56.0 years IQR 46.0-67.0) from Jinyintan Hospital and Wuhan Pulmonary Hospital found that odds of in-hospital death were higher in COVID-19 patients with coronary heart disease (OR: 21.40; 95\% CI 4.64-98.76, P < 0.0001); however, this evidence did not reach statistical significance at multivariate analysis.

A report of the Chinese Center for Disease Control and Prevention [60] showed that the all-cause death incidence rate was $2.3 \%$ with an average risk of death of 0.015 per patient observed for 10 days, among 44,672 confirmed cases in Mainland China. The crude case fatality rate was $2.8 \%$ for men and $1.7 \%$ for women, with the highest percentage $(14.8 \%)$ among octogenarians. The fatality rate in COVID-19 patients with cardiovascular diseases was higher than in those with no comorbidities $(10.5 \%$ vs. $0.9 \%)$, diabetes $(7.3 \%)$, chronic respiratory disease (6.3\%) and malignancy $(5.6 \%)$.

The most recent statistics emerging from Italy, which saw one of the largest and most serious clusters of COVID-19 in the world, showed that the case-fatality rate has been very high and is dominated by very old patients. According to the data by the COVID-19 Task Force of the Italian 
National Institute of Health about $60.7 \%$ of COVID-19 related deaths had three or more pre-existing chronic CVDs, $21.2 \%$ had two, and $14.4 \%$ at least one comorbidity. Hypertension (69.7\%), coronary artery disease $(27.4 \%)$ and diabetes $(31.9 \%)$ were the most prevalent cardiac comorbidities [61].

Peng et al. [62] from a large cohort of 406 COVID-19 patients admitted to the Western Hospital of Union Hospital in Wuhan performed a retrospective analysis to explore the clinical outcome of 112 COVID-19 patients with CVD (27.6\%), in particular hypertension (81.4\%), coronary artery disease (55.4\%) and heart failure (35.7\%). The total incidence of all-cause mortality was $15.18 \%(17 / 112)$; respiratory failure was the leading cause of death (64.7\%), followed by AMI (17.6\%). Compared to survived COVID-19 patients, non-surviving COVID-19 patients with CVD were more likely to have, or more often had, BMI $>25 \mathrm{~kg} / \mathrm{m} 2(88.2 \%$ vs. $18.95 \%, P<0.001)$, coronary heart disease $(88.24 \% \mathrm{vs}$. $49.47 \% ; p<0.03)$ and heart failure $(76.47 \%$ vs. $28.42 \%$; $p<0.001)$ [62].

In conclusion, from the analysis of published data it seems clear that COVID-19 patients with underlying CVD are more likely to develop a severe degree of the disease and death; however, there is currently no evidence that one specific $\mathrm{CV}$ risk factor could be per se an independent risk factor for severe complications or death in COVID-19. Based on severe and poor prognosis of COVID-19 patients with underlying CVD, this special group needs preventative and intensive treatment of past cardiovascular disease.

\section{Renin-Angiotensin-System (RAS) Inhibitors}

Previous studies have identified ACE2 as a functional receptor for HCoVs [7,8], including SARS-COV-2 [6]. ACE2 is a human homologue of ACE and degrades Angiotensin II to generate Angiotensin 1-7, thereby negatively regulating the renin-angiotensin system (RAS). Differently from its ubiquitous homologue ACE, ACE2 is abundantly expressed in airway epithelial cells and plays a crucial role in SARS-CoV-induced lung injury [63,64].

All published cohort studies analyzing the clinical features of COVID-19 patients showed hypertension and diabetes as the most prevalent cardiovascular comorbidities $[21,26,27]$. Based on the experimental data on the increased expression of ACE2 in patients with diabetes [11] and hypertension [65] while on ACE inhibitors (ACE-I) or angiotensin II type-I receptor blockers (ARBs) treatment, some authors [11,65-67] hypothesized that their use might increase the risk of SAR-COV-2 infection and develop a severe form of COVID-19, through the upregulation of ACE2 expression. Intravenous infusion of ACE inhibitors and angiotensin receptor blockers (ARBs) in experimental animal models increase the numbers of ACE2 receptors in the cardiopulmonary circulation [68].

Conversely, following the evidence of a reduced expression of ACE2 in the lungs of mice infected by SARS-CoV [63] and based on the attenuation of lung injury by blocking the renin-angiotensin pathway in the human cellular model [69], other authors [70] suggest a protective effect of ACE-I/ARBs from SARS-CoV-2 infection and worse presentation of the disease.

In any case, treatment with an ACEI or ARB may downregulate the expression of ACE2 but it seems not to have significant effect on its activity [71]. In fact, it has been demonstrated that there is a lack of correlation between the rise and fall of cardiac ACE2 mRNA expression and its activity: ACE2 mRNA expression increases with lisinopril isolated treatment, but ACE2 activity did not increase correspondingly, while cardiac ACE2 mRNA expression levels and activity increase after treatment with losartan alone [71].

Since ACE-Is bind the catalytic center rather than the receptor-binding domain (RBD) site of the receptor, they might indirectly alter the RBD of SARS-CoV-2 and thereby affect its interaction with ACE2 [10] (Figure 2).

An early experiment by Peng et al. [62], analyzing the impact of antihypertensive therapy on clinical outcome among 112 COVID-19 patients with cardiovascular disease, did not show any significant difference in ACE-I/ARB use percentage whether in COVID-19 critically ill patients compared to those with milder forms of disease, or in not-survived COVID-19 patients compared to survivors. A recent large Chinese study [72], analyzing the use of ACEIs/ARBs among 1178 COVID-19 patients with 
hypertension and other comorbidities, did not show differences in disease progression and mortality between patients treated with and without ACEIs/ARBs.

These data support the strong recommendations, by the main international cardiovascular scientific societies, to maintain or initiate ACEIs/ARBs treatment in patients with hypertension, heart failure or myocardial infarction, irrespective of SARS-CoV-2 infection, unless there is an alternative clinical reason to suspend them. Actually, the morbidity and mortality risk of stopping such drugs is significant, particularly given the myocardial damage that may occur and the lack of clinical or scientific evidence suggesting the discontinuation of this treatment in COVID-19 patients.

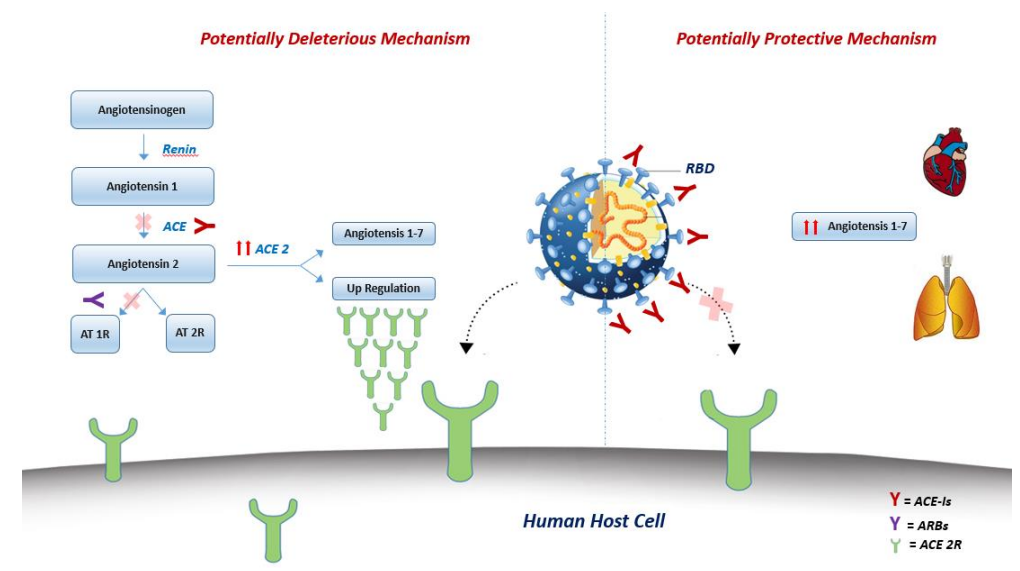

Figure 2. Conceptual figure showing the central role of the treatment with ACE inhibitors/ARBs in the potentially deleterious [left side picture] or protective [right side picture] effect on lungs in the clinical context of COVID-19. Potentially deleterious mechanism: renin-angiotensin-aldosterone system (RAAS) blocking drugs, such as ACE-Is and ARBs, might increase the activity of ACE 2 with consequent upregulation of ACE 2R, responsible of SARS-CoV-2 entry into host cells. Potentially protective mechanism: ACE-Is might bind the RBD of SARS-CoV-2 and thereby affect its interaction with ACE2, interfering host cells entry. Moreover, ACE2 might catalyze the conversion of angiotensin II to angiotensin 1-7, which acts as a vasodilator and exerts protective effects in the cardiovascular system. ACE-Is = ACE Inhibitors; ARBs = Angiotensin II type-I receptor blockers; $\mathrm{RBD}=$ Receptor-binding domain.

\section{Pharmacological COVID-19 Experimental Therapy and Cardiovascular Implication}

\subsection{Antiviral Drugs}

No specific antiviral drugs are available for SARS-CoV-2 infection. To date, the strategy consists in off-label administration of antiviral drugs effective in other viral infections.

\subsubsection{Remdesivir}

Remdesivir, an adenosine analogue, showed antiviral properties against SARS-Cov-2 infection and ability to block post-entry viral replication in an in-vitro study [73] and some case studies have reported clinical benefits in critically ill SARS-CoV-2 infected patients [74-76] There are several current clinical trials testing Remdesivir effects on COVID-19 patients [77]. On April 2020 Wang et al. published results of a randomized, double-blind, placebo-controlled, multicenter trial conducted to assess the effectiveness and safety of intravenous remdesivir on 237 SARS-CoV-2 patients [73]. No significant differences were found in the remdesivir group compared with placebo in time to clinical improvement but a trend toward a faster recovery was found in those patients with symptoms onset of less than 10 days. No significant differences were also found between groups for 28-day mortality. Adverse events were similar between groups, apparently lower in the remdesivir one; however, because of gastrointestinal symptoms, aminotransferase or bilirubin increases, and worsened cardiopulmonary status, a considerable proportion of patients on remdesivir had to prematurely stop the treatment [73] 
Other trials are certainly needed to confirm these findings especially on the use of remdesivir in the earlier stage of the disease due to the lack of representation of this subset of patients in the present study.

Generally, direct cardiovascular toxicity or specific medication interactions have yet to be reported for remdesivir. One case was previously described among 175 Ebola patients who developed severe hypotension and subsequent cardiac arrest after remdesivir loading dose [78].

\subsubsection{Favipiravir}

Favipiravir, a pyrazine carboxamide derivative, is the first approved antiviral drug by the National Medical Products Administration of China for the treatment of COVID-19 (www.nmpa.gov.cn). It has shown efficacy in treating the infection with minor side effects in a Chinese clinical trial including 70 COVID-19 patients (unpublished data). It was previously suggested that Favipiravir administered at high doses may contribute to QT interval prolongation in Ebolavirus infected patients [79]; however, this effect was lacking in healthy Japanese adults [80].

\subsubsection{Lopinavir/Ritonavir}

Lopinavir/Ritonavir, two protease inhibitors, did not significantly accelerate clinical improvement, reduce mortality, or diminish throat viral RNA detectability compared to standard care in a randomized clinical trial including 119 patients with severe COVID-19. Moreover, the Lopinavir/Ritonavir group showed more adverse events, especially gastrointestinal, leading 13 patients to stop treatment prematurely [81]. Lopinavir/Ritonavir may result in PR and QT interval prolongation and caution should be used in patients with baseline electrocardiographic abnormalities and those taking other QT prolonging drugs [82]. Lopinavir/ritonavir inhibits the activity of CYP3A4 [83] and P glycoprotein [84] and thereby may influence the activity of P2Y12 with implications on non-vitamin K oral anticoagulants and antiplatelet drugs serum concentrations [85] (Table 2).

Table 2. Adverse cardiovascular events with COVID-19 experimental therapies.

\begin{tabular}{cc}
\hline Drug & Adverse CV events \\
\hline Remdesivir & One case of severe hypotension and subsequent cardiac arrest after loading dose \\
Favipinavir & Uncertain QT interval prolongation at high doses \\
Lopinavir/Ritonavir & PR and QT interval prolongation \\
CQ/HCQ & QT interval prolongation; Bradyarrhythmias; Cardiomyopathy \\
Tocilizumab & Hypertension; Increased lipid levels \\
\hline
\end{tabular}

\subsection{Chloroquine and Hydroxychloroquine}

Chloroquine, an amine acidotropic form of quinine, is used for malaria treatment and prophylaxis [86], has immunomodulant and anti-inflammatory properties [87] and seems to have a broad-spectrum antiviral activity, by increasing endosomal $\mathrm{pH}$ required for virus/cell fusion, as well as interfering with the glycosylation of cellular receptors of SARS-CoV [87,88].

Recently, Wang et al, [73] evaluated in vitro five FDA-approved drugs (ribavirin, penciclovir, nitazoxanide, nafamostat, chloroquine) and two broad-spectrum antiviral drugs (remdesivir and favipiravir) in a clinically isolated SARS-CoV-2 patient. The authors concluded that chloroquine was effective and safe in the control of SARS-CoV-2 infection in vitro and suggested its assessment in COVID-19 patients. At least 23 different trials for SARS-CoV-2 already registered in the Chinese Clinical Trial Registry propose to use chloroquine or hydroxychloroquine in the treatment of COVID-19 [89].

Thus far, results from more than 100 patients demonstrated that chloroquine phosphate is superior to the control treatment in inhibiting the exacerbation of pneumonia, improving lung imaging findings, promoting a virus negative conversion, and shortening the disease course. Severe adverse reactions to chloroquine phosphate were not noted in the aforementioned patients [90]. Hydroxychloroquine, the 4-aminoquinoline form of chloroquine, has already demonstrated anti-SARS-CoV activity in vitro [91] and recently it was found to be more potent than chloroquine in inhibiting SARS-CoV-2 infection in an 
in-vitro study [92]. Currently various protocols are available for chloroquine and hydroxychloroquine administration according to different expert consensus documents [93,94].

Recently the Data Safety Monitoring Board of the Solidarity trial, an international clinical trial launched by the WHO and partners, selecting remdesivir, lopinavir/ritonavir, lopinavir/ritonavir with interferon beta-1a, and hydroxychloroquine as initial treatment options, has investigated data that emerged from a multinational registry analysis showing that the use of hydroxychloroquine or chloroquine with or without a macrolide for treatment of COVID-19 was associated with a decreased in-hospital survival and an increased frequency of ventricular arrhythmias. On June 32020 the WHO's Director-General announced that on the basis of the worldwide available mortality data there are no reasons to modify the Solidarity trial protocol, including the chloroquine and hydroxychloroquine arm, and the study by Mehera et al. was finally retracted $[95,96]$.

In any case, caution is required in establishing indications and contraindications for use of chloroquine in COVID-19 patients, with special mention to the pro-arrhythmic effects of the drug deriving from its ability to lengthen the QT tract [97] and subsequent risk of torsades de pointes [98-100]. Moreover bradyarrhythmias have been observed with hydroxychloroquine treatment [98,101,102], potentially leading to heart block with a stepwise manifestation beginning with right bundle branch block, then left anterior fascicular block, and ultimately third degree AV block [103], needing permanent pacemakers [102,104]. Major conduction abnormalities are more common in chronic use than in acute setting $[105,106]$ and more often associated with chloroquine than with hidroxychloroquine treatment [101].

Long-term chloroquine and hydroxycloroquine use is also associated with cardiomyopathy [107-111] often under recognized by healthcare providers [110], leading to preventable adverse events. Although cardiomyopathy phenotype can vary, the typical presentation is that of a non-genetic hypertrophic cardiomyopathy (MOGE(S) classification $\mathrm{M}_{\mathrm{H}} \mathrm{O}_{\mathrm{H}} \mathrm{G}_{\mathrm{N}} \mathrm{E}_{\mathrm{t}-\mathrm{CQ}}$ ) [112].

\subsection{Tocilizumab}

The cytokine storm seems to be a major determinant of COVID-19 clinical severity $[19,33,113,114]$. Tocilizumab, an interleukin-6 (IL-6) receptor antagonist, is currently approved by the Food and Drug Administration [FDA] for treatment of rheumatoid arthritis, giant cell arteritis, polyarticular juvenile idiopathic arthritis, systemic juvenile idiopathic arthritis and cytokine release syndrome (http://www.fda.gov). Encouraging but unpublished results have been obtained from off-label use of tocilizumab in COVID-19 patients. In this regard, the Italian Drug Agency (AIFA) has recently approved an ad hoc clinical trial for its use against SARS-CoV-2 infection (https://www.aifa.gov.it). Clinical trials comparing tocilizumab with continuous renal replacement therapy (CRRT) in cytokine release syndrome and combination therapy studies with tocilizumab and antiretroviral (favipiravir) therapy in COVID-19 patients have recently been registered $[115,116]$ The Food and Drug Administration warns that high blood pressure is one of the most common adverse events with tocilizumab [117]. Previous studies showed that tocilizumab was associated with increased mean lipid levels (total cholesterol, high-density lipoprotein (HDL) cholesterol, LDL cholesterol, and triglyceride) $[118,119]$ and interacts with CYP450 which is also implicated in atorvastatin metabolism [120]. These changes tend to occur within the first few weeks of treatment and remain stable during long-term therapy [121]. For this reason, prudent use of tocilizumab has always been made in patients with a high cardiovascular risk profile, with particular attention to dyslipidemic patients. Even so, a recent systematic review and network meta-analysis showed that, despite an increase in cholesterol levels, tocilizumab has safe cardiovascular outcomes compared to other antirheumatic drugs [122].

\subsection{Convalescent Plasma}

Among supportive care, convalescent plasma was found useful in previous SARS pandemics [123-125]. Empirical treatment with convalescent plasma had been approved during the Ebola virus outbreak in 2014 and a specific protocol was designed for MERS infection in 2015 [126]. Convalescent plasma reinfusion in 
H1N1 infection showed lower mortality, especially in the most serious patients, with no side effects [127]. Several case reports and case series have shown clinical benefits and no clinically relevant adverse effects with use of SARS-CoV-2 convalescent plasma reinfusion [128,129], so the treatment has been approved by the Chinese national health committee for critical ill patients [130]. To date there are at least 10 ongoing trials to assess effectiveness and efficacy of convalescent plasma for COVID-19 disease treatment [131].

\section{Drug interaction}

Major drug interactions are shown in Table 3.

Table 3. Major cardiovascular drug interaction with anti-SARS-CoV-2 drugs.

\begin{tabular}{|c|c|c|c|}
\hline & LP/RT & $\mathrm{CQ} / \mathrm{HCQ}$ & TCZ \\
\hline Acenocumarol & $\downarrow$ & $=$ & $\downarrow$ \\
\hline Warfarin & $\downarrow$ & $=$ & $\downarrow$ \\
\hline Apixaban * & $\uparrow$ & $\uparrow$ & $\downarrow$ \\
\hline Rivaroxaban & $\uparrow$ & $\uparrow$ & $\downarrow$ \\
\hline Edoxaban & $\uparrow$ & $\uparrow$ & $=$ \\
\hline Dabigatran & $\downarrow$ & $\uparrow$ & $=$ \\
\hline Prasugrel & $=$ & $=$ & $\downarrow$ \\
\hline Ticagrerol & $\uparrow$ & $=$ & $\downarrow$ \\
\hline Clopidogrel & $\downarrow$ & $=$ & $\downarrow$ \\
\hline Flecainide & $\Delta \uparrow$ & ${ }_{\Delta} \uparrow$ & $=$ \\
\hline Propafenone & ${ }_{\Delta} \boldsymbol{\uparrow}$ & ${ }_{\Delta}=$ & $=$ \\
\hline Dofetilide & $\uparrow$ & $=$ & $=$ \\
\hline Ibutilide & $=$ & $!=$ & $=$ \\
\hline Vernakalant & $=$ & $=$ & $=$ \\
\hline Amiodarone & $\uparrow$ & $\mathbf{\uparrow}$ & $=$ \\
\hline Lidocaine & $\uparrow$ & $=$ & $=$ \\
\hline Digoxin & $\uparrow$ & 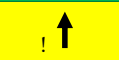 & $=$ \\
\hline $\mathrm{CCB}$ & $\uparrow$ & $=$ & $=$ \\
\hline Nicardipine & $\uparrow$ & $!=$ & $=$ \\
\hline Verapamil & $\uparrow$ & $\uparrow$ & $=$ \\
\hline Beta-blockers & $\uparrow$ & $=$ & $=$ \\
\hline Atorvastatin & $\uparrow$ & $=$ & $=$ \\
\hline Lovastatin & $\uparrow$ & $=$ & $=$ \\
\hline Simvastatin & $\uparrow$ & $=$ & $=$ \\
\hline
\end{tabular}

LP/RT:lopinavir/ritonavir; CQ/HCQ: chloroquine/hydroxychloroquine; TZC: tocilizumab; CCB: calcium-channel blockers Red box: avoid interaction; Yellow box: left drug levels needs monitoring; Green box: safe interaction; Arrows/equal symbols indicate what may happen to serum levels of listed drugs; Dashed arrow indicates what happens to anti-SARS-CoV-2 drug; ${ }^{*}$ The US SmPC suggests reduction of dose by $50 \%$ in patients taking $5 \mathrm{mg}$ BID and to avoid coadministration in patients already taking apixaban at $2.5 \mathrm{mg}$ BID; $\Delta$ : possible widening of QRS with increased risk of ventricular arrhythmias; !: QT prolongation. Modified from https://www.covid19-druginteractions.org/.

\section{Conclusions}

There is a bidirectional relationship between COVID-19 and CVD. If, on the one hand, patients with underlying CVD seem to be at higher risk of contracting COVID-19 and usually present a worse prognosis, on the other hand a not negligible number of infected patients experienced cardiovascular 
acute events in addition to other COVID-19 related complications. More attention should be paid to patients presenting with myocardial injury, defined by extremely increased cardiac troponin I (cTnI) levels or to new-onset arrhythmias, because these might deteriorate rapidly with ARDS, septic shock, MOF, and death. All physicians involved in COVID-19 management should be aware of the cardiovascular implications of the disease. Moreover, considering the high prevalence and worse prognosis of CVD among this population, we warmly recommend the presence of a cardiologist with extensive experience in intensive care medicine as essential part of the COVID-19 care team (Table 4). One of the main targets of the COVID-19 care team should be to create detailed protocol management of COVID-19 patients with cardiovascular complications and/or COVID-19 with pre-existing CVD, to guarantee the best care for patients and maximum safety for the healthcare providers, nurses and physicians.

Table 4. COVID-19 and HEART: HIGHLIGHTS.

\begin{tabular}{|c|}
\hline SARS-COv-2 may entry in myocardiocytes causing myocardial injury \\
\hline Cardiac damage biomarkers may identify COVID-19 patients at increased risk of worse clinical condition or death. \\
\hline Hypertension, diabetes, and coronary artery disease are the most prevalent comorbidities among COVID-19 patients. \\
\hline Fulminant myocarditis is a rare event and appears early in the clinical history of COVID-19 patients. \\
\hline Arrhythmias represent a not rare clinical presentation of COVID-19 and might complicate the clinical course of disease and worse the prognosis. \\
\hline The usual cardiovascular therapy, including the anti-hypertensive drugs, should be continued during the SARS-COV-2 pandemic. \\
\hline All physicians involved in COVID-19 management should be aware of cardiovascular implications of the disease \\
\hline A cardiologist with high experience in intensive care medicine should be part of COVID-19 care team. \\
\hline
\end{tabular}

Author Contributions: Conceptualization, V.R.; methodology, V.R.; software, A.A.P.; validation, P.G. and V.R.; formal analysis, A.C. and R.B.; resources, A.C. and R.B.; writing-original draft preparation, V.R., R.B. and A.C. writing-review and editing, V.R., A.R.; visualization, P.G.; supervision, G.N., P.G. and V.R. All authors have read and agreed to the published version of the manuscript.

Funding: This research received no external funding.

Acknowledgments: After the acceptance of the article, an unrestricted editorial support grant for open access publishing was provided by Novartis.

Conflicts of Interest: The authors declare no conflict of interest.

\section{References}

1. Hui, D.S.; Azhar, E.E.; Madani, T.A.; Ntoumi, F.; Kock, R.; Dar, O.; Ippolito, G.; McHugh, T.D.; Memish, Z.A.; Drosten, C.; et al. The continuing 2019-nCoV epidemic threat of novel coronaviruses to global health-The latest 2019 novel coronavirus outbreak in Wuhan, China. Int. J. Infect. Dis. 2020, 91, 264-266. [CrossRef] [PubMed]

2. Lu, R.; Zhao, X.; Li, J.; Niu, P.; Yang, B.; Wu, H.; Wang, W.; Song, H.; Huang, B.; Zhu, N.; et al. Genomic characterisation and epidemiology of 2019 novel coronavirus: Implications for virus origins and receptor binding. Lancet 2020, 395, 565-574. [CrossRef]

3. Wu, A.; Peng, Y.; Huang, B.; Ding, X.; Wang, X.; Niu, P.; Meng, J.; Zhu, Z.; Zhang, Z.; Wang, J.; et al. Genome Composition and Divergence of the Novel Coronavirus (2019-nCoV) Originating in China. Cell Host Microbe 2020, 27, 325-328. [CrossRef]

4. Li, F. Structure, Function, and Evolution of Coronavirus Spike Proteins. Annu. Rev. Virol. 2016, 3, $237-261$. [CrossRef] [PubMed]

5. Li, W.; Marx, J. Structure of SARS Coronavirus Spike Receptor-Binding Domain Complexed with Receptor. Science 2005, 309, 1864-1868. [CrossRef] [PubMed]

6. Xu, X.; Chen, P.; Wang, J.; Feng, J.; Zhou, H.; Li, X.; Zhong, W.; Hao, P. Evolution of the novel coronavirus from the ongoing Wuhan outbreak and modeling of its spike protein for risk of human transmission. Sci. China Life Sci. 2020, 63, 457-460. [CrossRef] 
7. Li, W.; Moore, M.J.; Vasilieva, N.; Sui, J.; Wong, S.K.; Berne, M.A.; Somasundaran, M.; Sullivan, J.L.; Luzuriaga, K.; Greenough, T.C.; et al. Angiotensin-converting enzyme 2 is a functional receptor for the SARS coronavirus. Nature 2003, 426, 450-454. [CrossRef]

8. Xiao, X.; Chakraborti, S.; Dimitrov, A.S.; Gramatikoff, K.; Dimitrov, D.S. The SARS-CoV S glycoprotein: Expression and functional characterization. Biochem. Biophys. Res. Commun. 2003, 312, 1159-1164. [CrossRef]

9. Zhou, P.; Yang, X.-L.; Wang, X.-G.; Hu, B.; Zhang, L.; Zhang, W.; Si, H.-R.; Zhu, Y.; Li, B.; Huang, C.-L.; et al. A pneumonia outbreak associated with a new coronavirus of probable bat origin. Nature 2020, 579, 270-273. [CrossRef]

10. Chen, Y.; Guo, Y.; Pan, Y.; Zhao, Z.J. Structure analysis of the receptor binding of 2019-nCoV. Biochem. Biophys. Res. Commun. 2020, 525, 135-140. [CrossRef]

11. Wan, Y.; Shang, J.; Graham, R.; Baric, R.S.; Li, F. Receptor Recognition by the Novel Coronavirus from Wuhan: An Analysis Based on Decade-Long Structural Studies of SARS Coronavirus. J. Virol. 2020, 94, 94. [CrossRef] [PubMed]

12. Crackower, M.A.; Sarao, R.; Oudit, G.Y.; Yagil, C.; Kozieradzki, I.; Scanga, S.E.; Oliveira-Dos-Santos, A.J.; Da Costa, J.; Zhang, L.; Pei, Y.; et al. Angiotensin-converting enzyme 2 is an essential regulator of heart function. Nature 2002, 417, 822-828. [CrossRef] [PubMed]

13. Danilczyk, U.; Sarao, R.; Remy, C.; Benabbas, C.; Stange, G.; Richter, A.; Arya, S.; Pospisilik, J.A.; Singer, D.; Camargo, S.; et al. Essential role for collectrin in renal amino acid transport. Nature 2006, 444, 1088-1091. [CrossRef] [PubMed]

14. Ding, Y.; He, L.; Zhang, Q.; Huang, Z.; Che, X.-Y.; Hou, J.; Wang, H.; Shen, H.; Qiu, L.; Li, Z.; et al. Organ distribution of severe acute respiratory syndrome (SARS) associated coronavirus (SARS-CoV) in SARS patients: Implications for pathogenesis and virus transmission pathways. J. Pathol. 2004, 203, 622-630. [CrossRef]

15. Zhao, Y.; Zhao, Z.; Wang, Y.; Zhou, Y.; Ma, Y.; Zuo, W. Single-cell RNA expression profiling of ACE2, the putative receptor of Wuhan 2019-nCov. bioRxiv 2020. [CrossRef]

16. Yang, J.-K.; Feng, Y.; Yuan, M.Y.; Yuan, S.Y.; Fu, H.J.; Wu, B.Y.; Sun, G.Z.; Yang, G.R.; Zhang, X.; Wang, L.; et al. Plasma glucose levels and diabetes are independent predictors for mortality and morbidity in patients with SARS. Diabet. Med. 2006, 23, 623-628. [CrossRef]

17. Badawi, A.; Ryoo, S.G. Prevalence of comorbidities in the Middle East respiratory syndrome coronavirus (MERS-CoV): A systematic review and meta-analysis. Int. J. Infect. Dis. 2016, 49, 129-133. [CrossRef]

18. Chen, N.; Zhou, M.; Dong, X.; Qu, J.; Gong, F.; Han, Y.; Qiu, Y.; Wang, J.; Liu, Y.; Wei, Y.; et al. Epidemiological and clinical characteristics of 99 cases of 2019 novel coronavirus pneumonia in Wuhan, China: A descriptive study. Lancet 2020, 395, 507-513. [CrossRef]

19. Huang, C.; Wang, Y.; Li, X.; Ren, L.; Zhao, J.; Hu, Y.; Zhang, L.; Fan, G.; Xu, J.; Gu, X.; et al. Clinical features of patients infected with 2019 novel coronavirus in Wuhan, China. Lancet 2020, 395, 497-506. [CrossRef]

20. Chen, C.; Yan, J.T.; Zhou, N.; Zhao, J.P.; Wang, D.W. Analysis of myocardial injury in patients with COVID-19 and association between concomitant cardiovascular diseases and severity of COVID-19. Zhonghua Xin Xue Guan Bing Za Zhi 2020, 48, E008.

21. Guan, W.-J.; Ni, Z.-Y.; Hu, Y.; Liang, W.-H.; Ou, C.-Q.; He, J.-X.; Liu, L.; Shan, H.; Lei, C.-L.; Hui, D.S.; et al. Clinical Characteristics of Coronavirus Disease 2019 in China. N. Engl. J. Med. 2020, 382, 1708-1720. [CrossRef] [PubMed]

22. Zhou, F.; Yu, T.; Du, R.; Fan, G.; Liu, Y.; Liu, Z.; Xiang, J.; Wang, Y.; Song, B.; Gu, X.; et al. Clinical course and risk factors for mortality of adult inpatients with COVID-19 in Wuhan, China: A retrospective cohort study. Lancet 2020, 395, 1054-1062. [CrossRef]

23. Wang, D.; Hu, B.; Hu, C.; Zhu, F.; Liu, X.; Zhang, J.; Wang, B.; Xiang, H.; Cheng, Z.; Xiong, Y.; et al. Clinical Characteristics of 138 Hospitalized Patients With 2019 Novel Coronavirus-Infected Pneumonia in Wuhan, China. JAMA 2020, 323, 1061. [CrossRef] [PubMed]

24. Zhang, J.-J.; Dong, X.; Cao, Y.-Y.; Yuan, Y.-D.; Yang, Y.-B.; Yan, Y.-Q.; Akdis, C.A.; Gao, Y.-D. Clinical characteristics of 140 patients infected with SARS-CoV-2 in Wuhan, China. Allergy 2020. [CrossRef]

25. Liu, K.; Fang, Y.-Y.; Deng, Y.; Liu, W.; Wang, M.-F.; Ma, J.-P.; Xiao, W.; Wang, Y.-N.; Zhong, M.-H.; Li, C.-H.; et al. Clinical characteristics of novel coronavirus cases in tertiary hospitals in Hubei Province. Chin. Med J. 2020, 133, 1025-1031. [CrossRef] 
26. Li, B.; Yang, J.; Zhao, F.; Zhi, L.; Wang, X.; Liu, L.; Bi, Z.; Zhao, Y. Prevalence and impact of cardiovascular metabolic diseases on COVID-19 in China. Clin. Res. Cardiol. 2020, 109, 531-538. [CrossRef]

27. Yang, J.; Zheng, Y.; Gou, X.; Pu, K.; Chen, Z.; Guo, Q.; Ji, R.; Wang, H.; Wang, Y.; Zhou, Y. Prevalence of comorbidities in the novel Wuhan coronavirus (COVID-19) infection: A systematic review and meta-analysis. Int. J. Infect. Dis. 2020. [CrossRef]

28. Richardson, S.; Hirsch, J.S.; Narasimhan, M.; Crawford, J.M.; McGinn, T.; Davidson, K.W.; Northwell, C.-R.C.; Barnaby, D.P.; Becker, L.B.; Chelico, J.D.; et al. Presenting Characteristics, Comorbidities, and Outcomes Among 5700 Patients Hospitalized With COVID-19 in the New York City Area. JAMA 2020. [CrossRef]

29. Russo, M.; Di Maio, M.; Attena, E.; Silverio, A.; Scudiero, F.; Celentani, D.; Lodigiani, C.; Di Micco, P. Clinical impact of pre-admission antithrombotic therapy in hospitalized patients with COVID-19: A multicenter observational study. Pharmacol. Res. 2020, 159, 104965. [CrossRef]

30. Turner, A.J.; Hiscox, J.A.; Hooper, N.M. ACE2: From vasopeptidase to SARS virus receptor. Trends Pharmacol. Sci. 2004, 25, 291-294. [CrossRef]

31. Thygesen, K.; Alpert, J.; Jaffe, A.S.; Chaitman, B.R.; Bax, J.J.; Morrow, D.A.; White, H.D.; Mickley, H.; Crea, F.; Van De Werf, F.; et al. Fourth universal definition of myocardial infarction (2018). Eur. Hear. J. 2018, 40, 237-269. [CrossRef]

32. Qin, C.; Zhou, L.; Hu, Z.; Zhang, S.; Yang, S.; Tao, Y.; Xie, C.; Ma, K.; Shang, K.; Wang, W.; et al. Dysregulation of Immune Response in Patients with COVID-19 in Wuhan, China. SSRN Electron. J. 2020. [CrossRef]

33. Channappanavar, R.; Perlman, S. Pathogenic human coronavirus infections: Causes and consequences of cytokine storm and immunopathology. Semin. Immunopathol. 2017, 39, 529-539. [CrossRef] [PubMed]

34. Mehta, P.; McAuley, D.F.; Brown, M.; Sanchez, E.; Tattersall, R.S.; Manson, J.J. HLH Across Speciality Collaboration, UK COVID-19: Consider cytokine storm syndromes and immunosuppression. Lancet 2020, 395, 1033-1034. [CrossRef]

35. Di Micco, P.; Russo, V.; Carannante, N.; Imparato, M.; Rodolfi, S.; Cardillo, G.; Lodigiani, C. Clotting Factors in COVID-19: Epidemiological Association and Prognostic Values in Different Clinical Presentations in an Italian Cohort. J. Clin. Med. 2020, 9, 1371. [CrossRef]

36. Lippi, G.; Lavie, C.J.; Sanchis-Gomar, F. Cardiac troponin I in patients with coronavirus disease 2019 (COVID-19): Evidence from a meta-analysis. Prog. Cardiovasc. Dis. 2020. [CrossRef]

37. National Center for Gerontology, N.C.R.C.f.G.D. Cardiovascular Branch of Chinese Geriatrics Society, Imaging Group of Cardiovascular Department, Beijing Medical Association. Expert Recommendations for Clinical Management of Myocardial Injury Associated With Coronavirus Disease 2019. Chin. Circ. J. 2020. [CrossRef]

38. Zeng, J.; Huang, J.; Pan, L. How to balance acute myocardial infarction and COVID-19: The protocols from Sichuan Provincial People's Hospital. Intensiv. Care Med. 2020, 1-3. [CrossRef]

39. ESC Guidance for the Diagnosis and Management of CV Disease during the COVID-19 Pandemic. 2020. Available online: https://www.escardio.org/Education/COVID-19-and-Cardiology/ESC-COVID19-Guidance (accessed on 20 March 2020).

40. Caforio, A.L.P.; Pankuweit, S.; Arbustini, E.; Basso, C.; Gimeno, J.R.; Felix, S.B.; Fu, M.; Heliö, T.; Heymans, S.; Jahns, R.; et al. Current state of knowledge on aetiology, diagnosis, management, and therapy of myocarditis: A position statement of the European Society of Cardiology Working Group on Myocardial and Pericardial Diseases. Eur. Hear. J. 2013, 34, 2636-2648. [CrossRef]

41. Ernandes, M.A.; Cantoni, A.M.; Armando, F.; Corradi, A.; Ressel, L.; Tamborini, A. Feline coronavirus-associated myocarditis in a domestic longhair cat. J. Feline Med. Surg. Open Rep. 2019, 5, 2055116919879256. [CrossRef]

42. Alhogbani, T. Acute myocarditis associated with novel Middle East respiratory syndrome coronavirus. Ann. Saudi Med. 2016, 36, 78-80. [CrossRef] [PubMed]

43. Inciardi, R.M.; Lupi, L.; Zaccone, G.; Italia, L.; Raffo, M.; Tomasoni, D.; Cani, D.S.; Cerini, M.; Farina, D.; Gavazzi, E.; et al. Cardiac Involvement in a Patient With Coronavirus Disease 2019 (COVID-19). JAMA Cardiol. 2020. [CrossRef] [PubMed]

44. Hu, H.; Ma, F.; Wei, X.; Fang, Y. Coronavirus fulminant myocarditis saved with glucocorticoid and human immunoglobulin. Eur. Heart J. 2020. [CrossRef]

45. Hua, A.; O'Gallagher, K.; Sado, D.; Byrne, J. Life-threatening cardiac tamponade complicating myo-pericarditis in COVID-19. Eur. Hear. J. 2020, 41, 2130. [CrossRef] [PubMed] 
46. Ruan, Q.; Yang, K.; Wang, W.; Jiang, L.; Song, J. Clinical predictors of mortality due to COVID-19 based on an analysis of data of 150 patients from Wuhan, China. Intensive Care Med. 2020. [CrossRef] [PubMed]

47. Zeng, J.H.; Liu, Y.; Jing, Y.; Wang, F.; Wu, W.-B.; Li, J.-X.; Wang, L.; Gao, H.; Wang, Y.; Dong, C.-F.; et al. First Case of COVID-19 Infection with Fulminant Myocarditis Complication: Case Report and Insights. Infection 2020, 1-5. [CrossRef]

48. Chen, C.; Zhou, Y.; Wang, D.-W. SARS-CoV-2: A potential novel etiology of fulminant myocarditis. Herz 2020, 45, 230-232. [CrossRef]

49. Deng, Y.; Liu, W.; Liu, K.; Fang, Y.-Y.; Shang, J.; Zhou, L.; Wang, K.; Leng, F.; Wei, S.; Chen, L.; et al. Clinical characteristics of fatal and recovered cases of coronavirus disease 2019 (COVID-19) in Wuhan, China. Chin. Med J. 2020. [CrossRef]

50. Onder, G.; Rezza, G.; Brusaferro, S. Case-Fatality Rate and Characteristics of Patients Dying in Relation to COVID-19 in Italy. JAMA 2020. [CrossRef]

51. Russo, V.; Rago, A.; Carbone, A.; Bottino, R.; Ammendola, E.; Della Cioppa, N.; Galante, D.; Golino, P.; Nigro, G. Atrial Fibrillation in COVID-19. J. Cardiovasc. Pharmacol. 2020. [CrossRef]

52. Guo, T.; Fan, Y.; Chen, M.; Wu, X.; Zhang, L.; He, T.; Wang, H.; Wan, J.; Wang, X.; Lu, Z. Cardiovascular Implications of Fatal Outcomes of Patients With Coronavirus Disease 2019 (COVID-19). JAMA Cardiol. 2020. [CrossRef] [PubMed]

53. Tan, Z.C.; Fu, L.H.; Wang, D.D.; Hong, K. Cardiac manifestations of patients with COVID-19 pneumonia and related treatment recommendations. Zhonghua Xin Xue Guan Bing Za Zhi 2020, 48, E005. [PubMed]

54. Zhu, Z.W.; Tang, J.J.; Chai, X.P.; Fang, Z.F.; Liu, Q.M.; Hu, X.Q.; Xu, D.Y.; Tang, L.; Tai, S.; Wu, Y.Z.; et al. Comparison of heart failure and 2019 novel coronavirus pneumonia in chest CT features and clinical characteristics. Zhonghua Xin Xue Guan Bing Za Zhi 2020, 48, E007. [PubMed]

55. Jiang, S.W.; Gao, H.; Wu, L.; Wang, G.W.; Cen, F.L.; Li, J.X.; Feng, C.; Wen, J.M.; Chen, Y.; He, R.L.; et al. Clinical feature changes of a COVID-19 patient from mild to critical condition and cardiopulmonary pathological results. Zhonghua Xin Xue Guan Bing Za Zhi 2020, 48, E018. [CrossRef]

56. Guidelines for adult cardiac failure of Extracorporeal Life Support Organization (ELSO), E. Available online: https://www.elso.org/Portals/0/IGD/Archive/FileManager/ e76ef78eabcusersshyerdocumentselsoguidelinesforadultcardiacfailure1.3.pdf (accessed on 20 May 2020).

57. Zeng, J.-H.; Liu, Y.-X.; Yuan, J.; Wang, F.-X.; Wu, W.-B.; Li, J.-X.; Wang, L.-F.; Gao, H.; Wang, Y.; Dong, C.-F.; et al. First case of COVID-19 complicated with fulminant myocarditis: A case report and insights. Infection 2020, 1-5. [CrossRef]

58. Chow, J.; Alhussaini, A.; Calvillo-Argüelles, O.; Billia, F.; Luk, A. Cardiovascular Collapse in COVID-19 Infection: The Role of Veno-Arterial Extracorporeal Membrane Oxygenation (VA-ECMO). CJC Open 2020. [CrossRef]

59. Rajagopal, K.; Keller, S.P.; Akkanti, B.; Bime, C.; Loyalka, P.; Cheema, F.H.; Zwischenberger, J.B.; El Banayosy, A.; Pappalardo, F.; Slaughter, M.S.; et al. Advanced Pulmonary and Cardiac Support of COVID-19 Patients: Emerging Recommendations From ASAIO_A “Living Working Document”. ASAIO J. 2020, 66, 588-598. [CrossRef]

60. Prevention, C.C.f.D.C.a. Centers for Disease Control and Prevention CfDCaP. Confirmed COVID-19 Cases Globally. Available online: wwwcdcgov/coronavirus/COVID-19/locations-confirmedcaseshtml\#map (accessed on 20 February 2020).

61. Istituto Superiore di Sanità (ISS). Report COVID 19. Available online: https://www.epicentro.iss.it/coronavirus/ aggiornamenti (accessed on 20 March 2020).

62. Peng, Y.D.; Meng, K.; Guan, H.Q.; Leng, L.; Zhu, R.R.; Wang, B.Y.; He, M.A.; Cheng, L.X.; Huang, K.; Zeng, Q.T. Clinical characteristics and outcomes of 112 cardiovascular disease patients infected by 2019-nCoV. Zhonghua Xin Xue Guan Bing Za Zhi 2020, 48, E004. [CrossRef]

63. Kuba, K.; Imai, Y.; Rao, S.; Gao, H.; Guo, F.; Guan, B.; Huan, Y.; Yang, P.; Zhang, Y.; Deng, W.; et al. A crucial role of angiotensin converting enzyme 2 (ACE2) in SARS coronavirus-induced lung injury. Nat. Med. 2005, 11, 875-879. [CrossRef]

64. Kuba, K.; Imai, Y.; Penninger, J.M. Angiotensin-converting enzyme 2 in lung diseases. Curr. Opin. Pharmacol. 2006, 6, 271-276. [CrossRef] 
65. Li, X.C.; Zhang, J.; Zhuo, J.L. The vasoprotective axes of the renin-angiotensin system: Physiological relevance and therapeutic implications in cardiovascular, hypertensive and kidney diseases. Pharmacol. Res. 2017, 125, 21-38. [CrossRef]

66. Fang, L.; Karakiulakis, G.; Roth, M. Are patients with hypertension and diabetes mellitus at increased risk for COVID-19 infection? Lancet Respir. Med. 2020, 8, e21. [CrossRef]

67. Vaduganathan, M.; Vardeny, O.; Michel, T.; McMurray, J.J.; Pfeffer, M.A.; Solomon, S.D. Renin-Angiotensin-Aldosterone System Inhibitors in Patients with Covid-19. N. Engl. J. Med. 2020, 382, 1653-1659. [CrossRef] [PubMed]

68. Diaz, J.H. Hypothesis: Angiotensin-converting enzyme inhibitors and angiotensin receptor blockers may increase the risk of severe COVID-19. J. Travel Med. 2020, 27. [CrossRef] [PubMed]

69. Jia, H.P.; Look, D.C.; Shi, L.; Hickey, M.; Pewe, L.; Netland, J.; Farzan, M.; Wohlford-Lenane, C.; Perlman, S.; McCray, P.B. ACE2 Receptor Expression and Severe Acute Respiratory Syndrome Coronavirus Infection Depend on Differentiation of Human Airway Epithelia. J. Virol. 2005, 79, 14614-14621. [CrossRef] [PubMed]

70. Sun, M.L.; Yang, J.M.; Sun, Y.P.; Su, G.H. Inhibitors of RAS Might Be a Good Choice for the Therapy of COVID-19 Pneumonia. Chin. J. Tuberc. Respir. Dis. 2020, 43, E014. [CrossRef]

71. Ferrario, C.M.; Jessup, J.; Chappell, M.C.; Averill, D.B.; Brosnihan, K.B.; Tallant, E.A.; Diz, D.I.; Gallagher, P.E. Effect of Angiotensin-Converting Enzyme Inhibition and Angiotensin II Receptor Blockers on Cardiac Angiotensin-Converting Enzyme 2. Circulation 2005, 111, 2605-2610. [CrossRef]

72. Li, J.; Wang, X.; Chen, J.; Zhang, H.; Deng, A. Association of Renin-Angiotensin System Inhibitors With Severity or Risk of Death in Patients With Hypertension Hospitalized for Coronavirus Disease 2019 (COVID-19) Infection in Wuhan, China. JAMA Cardiol. 2020. [CrossRef]

73. Wang, M.; Cao, R.; Zhang, L.; Yang, X.; Liu, J.; Xu, M.; Shi, Z.; Hu, Z.; Zhong, W.; Xiao, G. Remdesivir and chloroquine effectively inhibit the recently emerged novel coronavirus (2019-nCoV) in vitro. Cell Res. 2020, 30, 269-271. [CrossRef]

74. Bhatraju, P.K.; Ghassemieh, B.J.; Nichols, M.; Kim, R.; Jerome, K.R.; Nalla, A.K.; Greninger, A.L.; Pipavath, S.; Wurfel, M.M.; Evans, L.; et al. Covid-19 in Critically Ill Patients in the Seattle Region-Case Series. N. Engl. J. Med. 2020, 382, 2012-2022. [CrossRef]

75. Grein, J.; Ohmagari, N.; Shin, D.; Diaz, G.; Asperges, E.; Castagna, A.; Feldt, T.; Green, G.; Green, M.L.; Lescure, F.-X.; et al. Compassionate Use of Remdesivir for Patients with Severe Covid-19. N. Engl. J. Med. 2020. [CrossRef] [PubMed]

76. Holshue, M.L.; DeBolt, C.; Lindquist, S.; Lofy, K.H.; Wiesman, J.; Bruce, H.; Spitters, C.; Ericson, K.; Wilkerson, S.; Tural, A.; et al. First Case of 2019 Novel Coronavirus in the United States. N. Engl. J. Med. 2020, 382, 929-936. [CrossRef] [PubMed]

77. Available online: https://clinicaltrials.gov/ct2/results?cond=\&term=remdesivir\&cntry=\&state=\&city=\&dist= (accessed on 20 April 2020).

78. Mulangu, S.; Dodd, L.E.; Davey, R.T.; Mbaya, O.T.; Proschan, M.; Mukadi, D.; Manzo, M.L.; Nzolo, D.; Oloma, A.T.; Ibanda, A.; et al. A Randomized, Controlled Trial of Ebola Virus Disease Therapeutics. N. Engl. J. Med. 2019, 381, 2293-2303. [CrossRef] [PubMed]

79. Chinello, P.; Petrosillo, N.; Pittalis, S.; Biava, G.; Ippolito, G.; Nicastri, E. QTc interval prolongation during favipiravir therapy in an Ebolavirus-infected patient. PLoS Neglected Trop. Dis. 2017, 11, e0006034. [CrossRef]

80. Kumagai, Y.; Murakawa, Y.; Hasunuma, T.; Aso, M.; Yuji, W.; Sakurai, T.; Noto, M.; Oe, T.; Kaneko, A. Lack of effect of favipiravir, a novel antiviral agent, on QT interval in healthy Japanese adults. Int. J. Clin. Pharmacol. Ther. 2015, 53, 866-874. [CrossRef]

81. Cao, B.; Wang, Y.; Wen, D.; Liu, W.; Wang, J.; Fan, G.; Ruan, L.; Song, B.; Cai, Y.; Wei, M.; et al. A Trial of Lopinavir-Ritonavir in Adults Hospitalized with Severe Covid-19. N. Engl. J. Med. 2020, 382, 1787-1799. [CrossRef]

82. Rathbun, R.C.; Liedtke, M.D.; Blevins, S.M.; Harrison, N.; Lockhart, S.M.; Salvaggio, M.; Acosta, E.P. Electrocardiogram Abnormalities with Atazanavir and Lopinavir/Ritonavir. HIV Clin. Trials 2009, 10, 328-336. [CrossRef] 
83. Yeh, R.F.; Gaver, V.E.; Patterson, K.B.; Rezk, N.L.; Baxter-Meheux, F.; Blake, M.J.; Eron, J.J.; Klein, C.E.; Rublein, J.C.; Kashuba, A.D. Lopinavir/Ritonavir Induces the Hepatic Activity of Cytochrome P450 Enzymes CYP2C9, CYP2C19, and CYP1A2 But Inhibits the Hepatic and Intestinal Activity of CYP3A as Measured by a Phenotyping Drug Cocktail in Healthy Volunteers. JAIDS J. Acquir. Immune Defic. Syndr. 2006, 42, 52-60. [CrossRef]

84. Rolf, P.G.; Heeswijk, V.; Bourbeau, M.; Campbell, P.; Seguin, I.; Chauhan, B.M.; Foster, B.C.; Cameron, D.W.; Cameron, D.W. Time-Dependent Interaction Between Lopinavir/Ritonavir and Fexofenadine. J. Clin. Pharmacol. 2006, 46, 758-767. [CrossRef]

85. Russo, V.; Rago, A.; Proietti, R.; Di Meo, F.; Papa, A.A.; Calabrò, P.; D’Onofrio, A.; Nigro, G.; Alturki, A. Efficacy and safety of the target-specific oral anticoagulants for stroke prevention in atrial fibrillation: The real-life evidence. Ther. Adv. Drug Saf. 2016, 8, 67-75. [CrossRef]

86. White, N.J.; Pukrittayakamee, S.; Hien, T.T.; Faiz, M.A.; Mokuolu, O.A.; Dondorp, A.M. Malaria. Lancet 2014, 383, 723-735. [CrossRef]

87. Savarino, A.; Boelaert, J.R.; Cassone, A.; Majori, G.; Cauda, R. Effects of chloroquine on viral infections: An old drug against today's diseases. Lancet Infect. Dis. 2003, 3, 722-727. [CrossRef]

88. Colson, P.; Rolain, J.-M.; Raoult, D. Chloroquine for the 2019 novel coronavirus SARS-CoV-2. Int. J. Antimicrob. Agents 2020, 55, 105923. [CrossRef]

89. Available online: www.chictr.org.cn (accessed on 20 April 2020).

90. Gao, J.; Tian, Z.; Yang, X. Breakthrough: Chloroquine phosphate has shown apparent efficacy in treatment of COVID-19 associated pneumonia in clinical studies. Biosci. Trends 2020, 14, 72-73. [CrossRef]

91. Biot, C.; Daher, W.; Chavain, N.; Fandeur, T.; Khalife, J.; Dive, D.; De Clercq, E. Design and Synthesis of Hydroxyferroquine Derivatives with Antimalarial and Antiviral Activities. J. Med. Chem. 2006, 49, 2845-2849. [CrossRef]

92. Yao, X.; Ye, F.; Zhang, M.; Cui, C.; Huang, B.; Niu, P.; Liu, X.; Zhao, L.; Dong, E.; Song, C.; et al. In Vitro Antiviral Activity and Projection of Optimized Dosing Design of Hydroxychloroquine for the Treatment of Severe Acute Respiratory Syndrome Coronavirus 2 (SARS-CoV-2). Clin. Infect. Dis. 2020. [CrossRef]

93. Available online: http://www.simit.org/medias/1555-covid19-linee-guida-trattamento-01mar.pdf (accessed on 20 March 2020).

94. Available online: https://lci.rivm.nl/covid-19/bijlage/behandeladvies (accessed on 20 March 2020).

95. Mehra, M.R.; Desai, S.S.; Ruschitzka, F.; Patel, A.N. Hydroxychloroquine or chloroquine with or without a macrolide for treatment of COVID-19: A multinational registry analysis. Lancet 2020. [CrossRef]

96. Available online: https://www.who.int/emergencies/diseases/novel-coronavirus-2019/global-research-onnovell-coronavirus-2019-ncov/solidarity-cli-trial-for-covid-19-treatments (accessed on 20 March 2020).

97. multicenter collaboration group of Department of, S.; Technology of Guangdong, P.; Health Commission of Guangdong Province for chloroquine in the treatment of novel coronavirus, p. Expert consensus on chloroquine phosphate for the treatment of novel coronavirus pneumonia. Chin. J. Tuberc. Respir. Dis. 2020, 43, 185-188. [CrossRef]

98. Vereckei, A.; Fazakas, Á.; Baló, T.; Fekete, B.; Molnar, M.J.; Karádi, I. Chloroquine cardiotoxicity mimicking connective tissue disease heart involvement. Immunopharmacol. Immunotoxicol. 2013, 35, 304-306. [CrossRef] [PubMed]

99. Yap, Y.G.; Camm, A.J. Drug induced QT prolongation and torsades de pointes. Heart 2003, 89, $1363-1372$. [CrossRef]

100. Stas, P.; Faes, D.; Noyens, P. Conduction disorder and QT prolongation secondary to long-term treatment with chloroquine. Int. J. Cardiol. 2008, 127, e80-e82. [CrossRef] [PubMed]

101. Costedoat-Chalumeau, N.; Hulot, J.-S.; Amoura, Z.; Leroux, G.; Lechat, P.; Funck-Brentano, C.; Piette, J.-C. Heart conduction disorders related to antimalarials toxicity: An analysis of electrocardiograms in 85 patients treated with hydroxychloroquine for connective tissue diseases. Rheumatology 2007, 46, 808-810. [CrossRef] [PubMed]

102. Edwards, A.C.; Meredith, T.J.; Sowton, E. Complete heart block due to chronic chloroquine toxicity managed with permanent pacemaker. BMJ 1978, 1, 1109-1110. [CrossRef] [PubMed]

103. Tönnesmann, E.; Kandolf, R.; Lewalter, T. Chloroquine cardiomyopathy-A review of the literature. Immunopharmacol. Immunotoxicol. 2013, 35, 434-442. [CrossRef] [PubMed] 
104. Olken, D.; Volastro, P.; Finck, D.; Tulgan, H.; Mazur, P. Heart block in systemic lupus erythematosus complicated by Pacemaker "exit block". Arthritis Rheum. 1991, 34, 121-123. [CrossRef]

105. Woźniacka, A.; Cygankiewicz, I.; Chudzik, M.; Sysa-Jedrzejowska, A.; Wranicz, J.K. The cardiac safety of chloroquine phosphate treatment in patients with systemic lupus erythematosus: The influence on arrhythmia, heart rate variability and repolarization parameters. Lupus 2006, 15, 521-525. [CrossRef]

106. Acharya, D.; Robertson, P.; Kay, G.N.; Jackson, L.; Warnock, D.G.; Plumb, V.J.; Tallaj, J.A. Arrhythmias in Fabry Cardiomyopathy. Clin. Cardiol. 2012, 35, 738-740. [CrossRef]

107. Naqvi, T.Z.; Luthringer, D.; Marchevsky, A.; Saouf, R.; Gul, K.; Buchbinder, N.A. Chloroquine-induced cardiomyopathy-echocardiographic features. J. Am. Soc. Echocardiogr. 2005, 18, 383-387. [CrossRef] [PubMed]

108. Reffelmann, T.; Naami, A.; Spuentrup, E.; KuühlH, P. Contrast-Enhanced Magnetic Resonance Imaging of a Patient With Chloroquine-Induced Cardiomyopathy Confirmed by Endomyocardial Biopsy. Circulation 2006, 114, 357-358. [CrossRef] [PubMed]

109. Pieroni, M.; Smaldone, C.; Camporeale, A.; Ierardi, C.; Dell'Antonio, G.; Bellocci, F.; Crea, F. Chloroquine-Induced Transition From Dilated to Restrictive Cardiomyopathy. J. Am. Coll. Cardiol. 2011, 57, 515. [CrossRef] [PubMed]

110. Tönnesmann, E.; Stroehmann, I.; Kandolf, R.; Wolburg, H.; Strach, K.; Musshoff, F.; Tiemann, K.; Lewalter, T. Cardiomyopathy Caused by Longterm Treatment with Chloroquine: A Rare Disease, or a Rare Diagnosis? J. Rheumatol. 2012, 39, 1099-1103. [CrossRef] [PubMed]

111. Frustaci, A.; Morgante, E.; Antuzzi, D.; Russo, M.A.; Chimenti, C. Inhibition of cardiomyocyte lysosomal activity in hydroxychloroquine cardiomyopathy. Int. J. Cardiol. 2012, 157, 117-119. [CrossRef] [PubMed]

112. Arbustini, E.; Narula, N.; Dec, G.W.; Reddy, K.S.; Greenberg, B.; Kushwaha, S.; Marwick, T.; Pinney, S.; Bellazzi, R.; Favalli, V.; et al. The MOGE(S) Classification for a Phenotype-Genotype Nomenclature of Cardiomyopathy. J. Am. Coll. Cardiol. 2013, 62, 2046-2072. [CrossRef] [PubMed]

113. Williams, A.E.; Chambers, R.C. The mercurial nature of neutrophils: Still an enigma in ARDS? Am. J. Physiol. Cell. Mol. Physiol. 2013, 306, L217-L230. [CrossRef]

114. Cameron, M.J.; Bermejo-Martin, J.F.; Danesh, A.; Muller, M.P.; Kelvin, D.J. Human immunopathogenesis of severe acute respiratory syndrome (SARS). Virus Res. 2008, 133, 13-19. [CrossRef]

115. Available online: https://clinicaltrials.gov/ct2/show/NCT04306705 (accessed on 20 March 2020).

116. Available online: https://clinicaltrials.gov/ct2/show/NCT0431022 (accessed on 20 March 2020).

117. The Food and Drug administration. Available online: https://www.fda.gov/ (accessed on 20 March 2020).

118. Smolen, J.S.; Beaulieu, A.; Rubbert-Roth, A.; Ramos-Remus, C.; Rovensky, J.; Alecock, E.; Woodworth, T.G.; Alten, R. Effect of interleukin-6 receptor inhibition with tocilizumab in patients with rheumatoid arthritis (OPTION study): A double-blind, placebo-controlled, randomised trial. Lancet 2008, 371, 987-997. [CrossRef]

119. Gabay, C.; Emery, P.; Van Vollenhoven, R.; Dikranian, A.; Alten, R.; Pavelka, K.; Klearman, M.; Musselman, D.; Agarwal, S.; Green, J.; et al. Tocilizumab monotherapy versus adalimumab monotherapy for treatment of rheumatoid arthritis (ADACTA): A randomised, double-blind, controlled phase 4 trial. Lancet 2013, 381, 1541-1550. [CrossRef]

120. Bellosta, S.; Corsini, A. Statin drug interactions and related adverse reactions: An update. Expert Opin. Drug Saf. 2017, 17, 25-37. [CrossRef]

121. Genovese, M.C.; Rubbert-Roth, A.; Smolen, J.S.; Kremer, J.M.; Khraishi, M.; Gómez-Reino, J.; Sebba, A.; Pilson, R.; Williams, S.; Van Vollenhoven, R. Longterm Safety and Efficacy of Tocilizumab in Patients with Rheumatoid Arthritis: A Cumulative Analysis of Up to 4.6 Years of Exposure. J. Rheumatol. 2013, 40, 768-780. [CrossRef]

122. Castagné, B.; Viprey, M.; Martin, J.; Schott, A.-M.; Cucherat, M.; Soubrier, M. Cardiovascular safety of tocilizumab: A systematic review and network meta-analysis. PLoS ONE 2019, 14, e0220178. [CrossRef]

123. Lai, S.T. Treatment of severe acute respiratory syndrome. Eur. J. Clin. Microbiol. Infect. Dis. 2005, $24,583-591$. [CrossRef] [PubMed]

124. Soo, Y.; Cheng, Y.; Wong, R.S.; Hui, D.S.; Lee, C.; Tsang, K.; Ng, M.; Chan, P.K.; Cheng, G.; Sung, J.J.Y. Retrospective comparison of convalescent plasma with continuing high-dose methylprednisolone treatment in SARS patients. Clin. Microbiol. Infect. 2004, 10, 676-678. [CrossRef] [PubMed] 
125. Cheng, Y.; Wong, R.S.; Soo, Y.O.Y.; Wong, W.S.; Lee, C.K.; Ng, M.H.L.; Chan, P.; Wong, K.C.; Leung, C.B.; Cheng, G. Use of convalescent plasma therapy in SARS patients in Hong Kong. Eur. J. Clin. Microbiol. Infect. Dis. 2004, 24, 44-46. [CrossRef] [PubMed]

126. Arabi, Y.M.; Balkhy, H.H.; Hajeer, A.H.; Bouchama, A.; Hayden, F.G.; Al-Omari, A.; Al-Hameed, F.; Taha, Y.; Shindo, N.; Whitehead, J.; et al. Feasibility, safety, clinical, and laboratory effects of convalescent plasma therapy for patients with Middle East respiratory syndrome coronavirus infection: A study protocol. SpringerPlus 2015, 4, 709. [CrossRef] [PubMed]

127. Xia, S.; Zhu, Y.; Liu, M.; Lan, Q.; Xu, W.; Wu, Y.; Ying, T.; Liu, S.; Shi, Z.; Jiang, S.; et al. Fusion mechanism of 2019-nCoV and fusion inhibitors targeting HR1 domain in spike protein. Cell. Mol. Immunol. 2020, 1-3. [CrossRef] [PubMed]

128. Shen, C.; Wang, Z.; Zhao, F.; Yang, Y.; Li, J.; Yuan, J.; Wang, F.; Li, D.; Yang, M.; Xing, L.; et al. Treatment of 5 Critically Ill Patients With COVID-19 With Convalescent Plasma. JAMA 2020, 323, 1582. [CrossRef]

129. Duan, K.; Liu, B.; Li, C.; Zhang, H.; Yu, T.; Qu, J.; Zhou, M.; Chen, L.; Meng, S.; Hu, Y.; et al. The feasibility of convalescent plasma therapy in severe COVID-19 patients: A pilot study. medRxiv 2020. [CrossRef]

130. Lin, L.; Li, T.S. Interpretation of "Guidelines for the Diagnosis and Treatment of Novel Coronavirus (2019-nCoV) Infection by the National Health Commission (Trial Version 5)". Zhonghua Yi Xue Za Zhi 2020, 100, E001. [CrossRef]

131. Available online: https://clinicaltrials.gov/ct2/results? cond=COVID19\&term=convalescent+plasma\&cntry= \&state $=\&$ city $=\&$ dist $=($ accessed on 15 March 2020).

(C) 2020 by the authors. Licensee MDPI, Basel, Switzerland. This article is an open access article distributed under the terms and conditions of the Creative Commons Attribution (CC BY) license (http://creativecommons.org/licenses/by/4.0/). 